\title{
A!
}

This is an electronic reprint of the original article.

This reprint may differ from the original in pagination and typographic detail.

Hellsten, Niko; Taskinen, Pekka; Johto, Hannu; Jokilaakso, Ari

\section{Trace Metal Distributions in Nickel Slag Cleaning}

\section{Published in:}

Extraction 2018

DOI:

10.1007/978-3-319-95022-8_30

Published: 01/01/2018

Document Version

Peer reviewed version

Published under the following license:

Unspecified

Please cite the original version:

Hellsten, N., Taskinen, P., Johto, H., \& Jokilaakso, A. (2018). Trace Metal Distributions in Nickel Slag Cleaning.

In B. Davis, M. Moats, \& S. Wang (Eds.), Extraction 2018: Proceedings of the First Global Conference on

Extractive Metallurgy (pp. 379-389). (The Minerals, Metals \& Materials Series). SPRINGER.

https://doi.org/10.1007/978-3-319-95022-8_30

This material is protected by copyright and other intellectual property rights, and duplication or sale of all or part of any of the repository collections is not permitted, except that material may be duplicated by you for your research use or educational purposes in electronic or print form. You must obtain permission for any other use. Electronic or print copies may not be offered, whether for sale or otherwise to anyone who is not an authorised user. 


\title{
Trace metal distributions in nickel slag cleaning
}

\author{
Niko Hellstén ${ }^{\mathrm{a}, *}$, Pekka Taskinen ${ }^{\mathrm{a}}$, Hannu Johto $^{\mathrm{b}}$ and Ari Jokilaakso ${ }^{\mathrm{a}}$ \\ ${ }^{a}$ Aalto University, School of Chemical Engineering, P.O. Box 16200, Espoo (Finland)

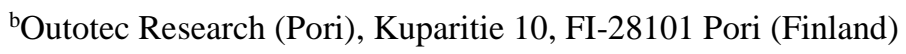 \\ *=Corresponding author, Tel.: +358-40-719 6323, email: niko.hellsten@ aalto.fi
}

\section{Abstract}

To capture efficiently the valuable trace metals from nickel slag using electric furnace, it is important to study their distributions between the slag and metallic phases in the furnace. It is impossible to calculate accurately these distributions without experimental measurements. Therefore, in this work, selected trace metal distributions and phase equilibria between $\mathrm{K}_{2} \mathrm{O}$ containing iron-silicate slags and a metallic $\mathrm{Ni}-\mathrm{Fe}-\mathrm{Cu}$ alloy in nickel slag cleaning furnace conditions were studied. The experimental method developed and applied during the work, involved a modified quenching technique that included equilibration of the samples in semi-sealed quartz ampoules in an inert atmosphere and metallic Fe saturation. The use of the semi-sealed quartz ampoule prevents the escape of volatile elements from the sample during equilibration. Chemical compositions of the phases and the trace elements were analysed by EPMA. From the measured compositions, the trace metal distribution coefficients between the molten $\mathrm{Ni}-\mathrm{Fe}-\mathrm{Cu}$ alloy and slag were calculated.

Keywords: Ni slag cleaning, Distribution of $\mathrm{Ag}, \mathrm{Au}, \mathrm{Sb}$ and $\mathrm{Pb}$, Semi-closed ampoule

\section{Introduction}

Most pure nickel is produced from sulphidic ores by smelting. Typically, in the smelting of Ni-bearing concentrate, economically important amounts of $\mathrm{Ni}$ as well as metal values (for example $\mathrm{Co}$, PGMs, $\mathrm{Ag}$ and $\mathrm{Au}$ ) remain in the slag phase as entrained matte (or as dissolved oxides). To recover the metal values, the slag is cleaned in an electric furnace under reducing conditions [1]. The aim in this process is to reduce the oxidized and dissolved metals so that they would report to a liquid metallic phase consisting mainly of Fe and Ni. Optimization of the metal recovery requires experimental determination of the distribution of the metals between slag and metallic phase at the process conditions. However, due to the high vapour pressures of some of the metal values, for example $\mathrm{Ag}, \mathrm{Pb}$ and $\mathrm{Sb}$, they may volatilise under the experimental conditions [2]. Therefore, experimental determination of their distributions in the molten phases is challenging. Development of an experimental method to study the behavior of the volatile elements would be of value in the research. The use of sealed ampoules in experiments is an established method. However, the downside of a sealed ampoule is that control of the gas atmosphere is difficult. Recently, Tirronen et al. [3] conducted experiments using an ampoule design with a hole, to enable gas atmosphere from outside the ampoule to equilibrate with the atmosphere inside.

The aim of this work was to develop and test a semi-closed ampoule technique to study equilibrium behavior of the volatile elements $\mathrm{Ag}, \mathrm{Pb}$ and $\mathrm{Sb}$. We made a hypothesis, that the semi-closed ampoule forms a kinetic barrier for the saturated gas phase above the liquid slag and alloy so that the volatile elements remain in the condensed phases 
during equilibration. In addition, the saturated gas phase should prevent further volatilization. An advantage of this method is that the gas atmosphere inside the ampoule can be controlled externally by, e.g., CO-CO $\mathrm{CO}_{2}$ mixtures. Using a semi-closed ampoule, the distributions of volatile trace elements $\mathrm{Ag}, \mathrm{Pb}$ and $\mathrm{Sb}$ and non-volatile Au between $\mathrm{K}_{2} \mathrm{O}$ containing iron-silicate slag of fixed $\mathrm{Fe} / \mathrm{SiO}_{2}$ ratio and a liquid $\mathrm{Cu}-\mathrm{Fe}-\mathrm{Ni}$ metal alloy, at solid $\mathrm{Fe}$ alloy saturation, were studied at $1400{ }^{\circ} \mathrm{C}$ by equilibration in reducing conditions and quenching. The previous research on the behavior of many impurity elements available in the current experimental conditions is scarce [4] and it is evident that the published data are biased by the trace element volatilization [5]. The distributions of these elements between the slag, a liquid $\mathrm{Cu}-\mathrm{Fe}-\mathrm{Ni}$ alloy and solid $\mathrm{Fe}$ alloy were studied as a function of the $\mathrm{Fe} / \mathrm{Ni}$ ratio in the liquid alloy. The used experimental conditions were chosen because they closely resemble the industrial process [6]. Because Ag, $\mathrm{Pb}$ and $\mathrm{Sb}$ have been found to volatilise rapidly under the experimental conditions [7], a novel semi-closed ampoule technique was developed and tested in this work.

\section{Materials and methods}

The $\mathrm{Cu}-\mathrm{Fe}-\mathrm{Ni}$ alloy, iron silicate slag and $\mathrm{Fe}$ foil crucibles used in the experiments were prepared from high-purity chemicals (Table I). The semi-closed ampoule was made of fused pure quartz.

Table I. Purities and suppliers of the chemicals used.

\begin{tabular}{|l|l|l|}
\hline $\mathrm{Chemical}$ & Purity (wt-\%) & Supplier \\
\hline $\mathrm{Cu}$ & 99.999 & Alfa-Aesar \\
\hline $\mathrm{Ni}$ & 99.996 & Alfa-Aesar \\
\hline $\mathrm{Fe}$ & 99.99 & Alfa-Aesar \\
\hline $\mathrm{Fe}$ foil, $0.25 \mathrm{~mm}$ (for crucibles) & 99.99 & Alfa-Aesar \\
\hline $\mathrm{SiO}_{2}$ & 99.99 & Umicore \\
\hline $\mathrm{Fused} \mathrm{quartz} \mathrm{glass} \mathrm{(for} \mathrm{ampoules)}$ & 99.99 & Finnish Special Glass \\
\hline $\mathrm{Fe}_{2} \mathrm{O}_{3}$ & 99.99 & Alfa-Aesar \\
\hline $\mathrm{K}_{2} \mathrm{CO}_{3}$ (as a source of $\left.\mathrm{K}_{2} \mathrm{O}\right)$ & $99.5-100.5$ & Sigma-Aldrich \\
\hline $\mathrm{Ag}$ & 99.99 & Alfa-Aesar \\
\hline $\mathrm{Au}$ & 99.96 & Alfa-Aesar \\
\hline $\mathrm{Pb}$ & 99.999 & Alfa-Aesar \\
\hline $\mathrm{Sb}$ & 99.999 & Cerac \\
\hline
\end{tabular}

\subsection{Synthesis of $\mathrm{Cu}-\mathrm{Fe}-\mathrm{Ni}$ alloy}

We synthesized four $\mathrm{Cu}-\mathrm{Fe}-\mathrm{Ni}$ alloys of varying $\mathrm{Fe} / \mathrm{Ni}$ ratio for the equilibration experiments, see Table II. According to the calculated phase diagram [8], iron and nickel form a single solid alloy at $1400{ }^{\circ} \mathrm{C}$ that covers the whole concentration range of the system at low copper concentrations. To obtain a molten metallic phase in the experiments, $\mathrm{Cu}$ was added to the alloy. In contrast, in slag cleaning in real industrial process conditions the metallic phase, forming electric furnace matte, is molten due to alloying elements lowering its melting temperature [9]. For synthesis, we weighed and mixed pure metal powders of $\mathrm{Cu}, \mathrm{Fe}$ and $\mathrm{Ni}$ in the desired ratios. Subsequently, the mixtures were heat treated in a horizontal tube furnace at $1400{ }^{\circ} \mathrm{C}$ in pure $\mathrm{Al}_{2} \mathrm{O}_{3}$ crucibles supported by an alumina boat. We used an atmosphere of $99 \% \mathrm{Ar}\left(99.99 \%\right.$, Linde Aga) and $1 \%$ of $\mathrm{H}_{2}(99.99 \%$, Linde Aga) in the synthesis to avoid oxidation of the metals. The furnace was heated to $1400{ }^{\circ} \mathrm{C}$ at a rate of $4{ }^{\circ} \mathrm{C} / \mathrm{min}$, held at the target temperature overnight and cooled to room temperature $4{ }^{\circ} \mathrm{C} / \mathrm{min}$.

From a visual observation, the alloys containing $40 \mathrm{wt}-\%$ and $30 \mathrm{wt}-\%$ of Ni looked more completely molten than the ones containing $60 \mathrm{wt}-\%$ and $50 \mathrm{wt}-\%$ of $\mathrm{Ni}$, respectively. The samples containing more nickel contained edged crystal shapes, which were probably solid precipitates formed in the slow cooling process. Table III shows the average elemental compositions of the synthesized $\mathrm{Cu}-\mathrm{Fe}-\mathrm{Ni}$ alloys after melting, as measured by EDS. 


\subsection{Preparation of sample, Fe crucible and the semi-closed ampoule}

An iron crucible (length $30 \mathrm{~mm}$, outer diameter of $5.8 \mathrm{~mm}$ or less) was prepared from $0.25 \mathrm{~mm}$ thick pure Fe foil by rolling and wrapping into a crucible shape. The bottom of the 'crucible' was pressed tight using pliers. The iron saturated iron-silicate based slag mixture was prepared by mixing $\mathrm{Fe}, \mathrm{Fe}_{2} \mathrm{O}_{3}, \mathrm{SiO}_{2}$ and $\mathrm{K}_{2} \mathrm{O}$ (obtained from a prereacted and premelted $\mathrm{SiO}_{2}-\mathrm{K}_{2} \mathrm{CO}_{3}$ mixture) powders to form a slag, which contains 32 wt- $\%$ of $\mathrm{SiO}_{2}$ and 2 wt- $\%$ of $\mathrm{K}_{2} \mathrm{O}$ in equilibrium. In addition, $1 \mathrm{wt}-\%$ of $\mathrm{Ag}, \mathrm{Au}, \mathrm{Pb}$ and $\mathrm{Sb}$ were added as powders into the slag mixture. The $\mathrm{Cu}-$ $\mathrm{Fe}-\mathrm{Ni}$ alloy and slag were inserted into the Fe crucible. Because the alloy and slag react strongly with the foil at the experimental temperature, pure Fe flakes were added in the bottom of the crucible to protect its integrity during experiments. Pure Fe, the $\mathrm{Cu}-\mathrm{Fe}-\mathrm{Ni}$ alloy and slag containing the trace elements each weighed $0.2 \mathrm{~g}$, and thus their corresponding weight ratios were $1: 1: 1$.

The semi-sealed ampoule was formed from a quartz tube (8 mm OD, 6 mm ID; Heraeus: HSQ 300$)$. A 1.9 mm diameter hole was drilled into the ampoule $40 \mathrm{~mm}$ above the bottom of the tube using a dentist's drill (NSK Presto Aqua II, NSK, Japan) and a natural diamond ball point drill head (Intensiv, Switzerland). The iron foil crucible containing the sample was inserted into the tube. Subsequently, the quartz tube was cut to $50-80 \mathrm{~mm}$ length and a hook for suspension was formed on the top-end using a hydrogen-oxygen torch. This operation left the drilled hole as the only opening into the ampoule to the surrounding furnace atmosphere. Figure 1 shows a schematic of the semi-sealed ampoule containing the Fe crucible and the sample inside.

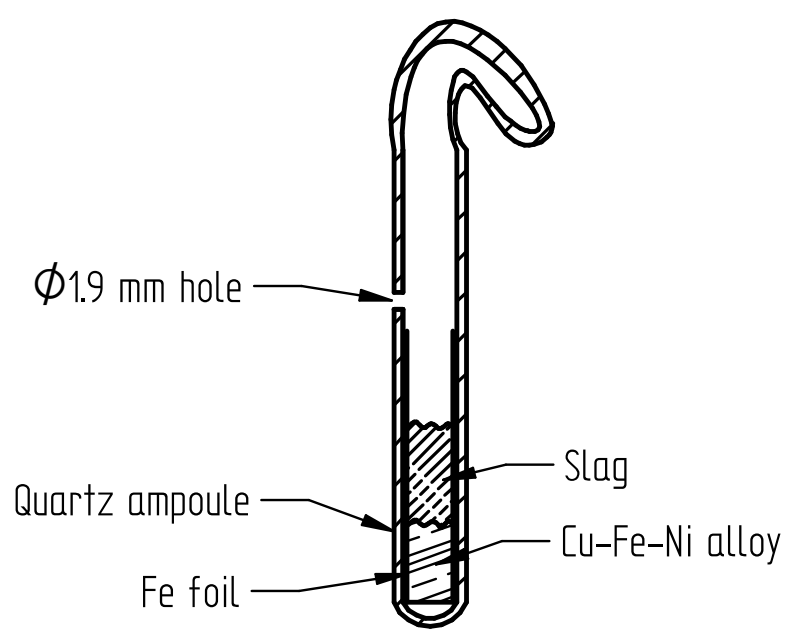

Figure 1. Schematic of the cross-section of the semi-sealed ampoule, iron foil crucible and the slag-alloy sample.

In this method, we assumed that the semi-sealed ampoule forms a kinetic barrier for the volatile elements. During experimentation, the gas phase above the liquid slag saturates with the volatile elements. The small hole decreases the removal rate of the saturated gas phase, by Knudsen-like gas diffusion, while the saturated gas phase reduces transfer of the volatile elements from the condensed phases into the gas flow. Thus, it was expected that the volatile elements equilibrate between slag and alloy, and remain in the sample after quenching in sufficient amounts for in situ analysis with EPMA (Electron probe X-ray microanalysis) or LA-ICP-MS (Laser ablation-inductively coupled plasma-mass spectrometry). In equilibrium, the ratio and thus the distribution coefficient of the metals between the $\mathrm{Cu}-\mathrm{Fe}-\mathrm{Ni}$ alloy, slag and metallic Fe, remains the same regardless of evaporation of the metals if the diffusional mass transfer in the slag and alloy are faster than the volatilisation. Figure 2 illustrates the new concept. 


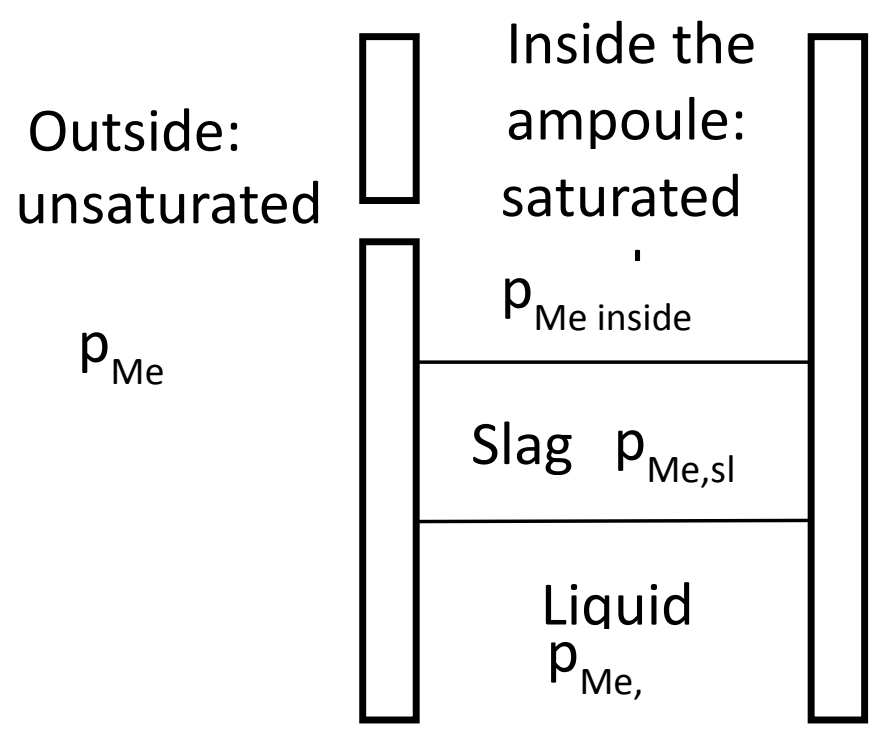

Figure 2. Schematic of the gas phase arrangement and the expected behavior in the experimental technique used.

When $\mathrm{p}_{\mathrm{Me}, \mathrm{sl}}, \mathrm{p}_{\mathrm{M}, \mathrm{M}}<\mathrm{p}_{\mathrm{Me}, \text { inside, }}$, volatilization of the metal/oxide to the surrounding furnace atmosphere will occur but it is assumed to be slow compared to vaporization processes on the slag surface. When $\mathrm{p}_{\mathrm{Me} \text {,inside }}<\mathrm{p}_{\mathrm{Me}, \text { outside, }}$, the metal /oxide containing gas moves outside the ampoule through the hole. In this experimental arrangement, the molten alloy-solid alloy equilibrium with $\mathrm{FeO}$ in the slag forms the prevailing oxygen pressure in the ampoule.

\subsection{Experimental method}

The equilibration experiments were conducted in a vertical tube furnace at $1400{ }^{\circ} \mathrm{C}$ under $\mathrm{N}_{2}$ (Nitrogen 5.0, $\geq 99.999$ $\%$, Aga Linde) atmosphere using a similar setup and method as described earlier [10]. The semi-sealed ampoule containing the sample was introduced into the furnace work tube from its lower end and suspended there with a 0.5 $\mathrm{mm}$ Pt-wire. The ampoule was kept in the low end while the furnace was sealed, and the gas atmosphere flushed with flowing $\mathrm{N}_{2}$ for 30 minutes, at $200 \mathrm{~mL} / \mathrm{min}$ flow rate. After flushing, the ampoule was raised to the hot zone of the furnace, equilibrated for 4 hours and quenched into a $0{ }^{\circ} \mathrm{C}$ ice-water mixture. During experiments, temperature of the sample was monitored using a calibrated S-type Pt-Pt90/Rh10 thermocouple.

Time required for equilibration was determined experimentally as 4 hours based on changes in the slag composition. After quenching, the sample was dried, mounted into epoxy and polished using wet metallographic methods. The sample was made conductive carbon coating by evaporation.

Microstructure observations and preliminary analysis of chemical compositions of the phases were conducted using SEM-EDS (LEO SEM 1450 - Oxford Instruments X-Max $50 \mathrm{~mm}^{2}$ EDS + INCA). The accurate chemical phase compositions were carried out by EPMA (Cameca SX100). The EPMA was operated using $20 \mathrm{kV}$ accelerating voltage, $40 \mathrm{nA}$ beam current and $50 \mu \mathrm{m}-100 \mu \mathrm{m}$ beam diameters. A PAP matrix correction program supplied by the manufacturer was used to correct the analytical results. The external standard materials and analysed lines used in the EPMA analysis were $\mathrm{Fe} \mathrm{K}_{\alpha}$ and $\mathrm{O} \mathrm{K}_{\alpha}$ (hematite), $\mathrm{Si} \mathrm{K}_{\alpha}$ (quartz), $\mathrm{K} \mathrm{K}_{\alpha}$ (sanidine), $\mathrm{Cu} \mathrm{K}_{\alpha}(\mathrm{Cu}), \mathrm{Ni} \mathrm{K}_{\alpha}(\mathrm{Ni}), \mathrm{Ag}$ $\mathrm{L}_{\beta}(\mathrm{Ag}), \mathrm{Sb} \mathrm{L}_{\alpha}$ (Sb-telluride), $\mathrm{Au} \mathrm{L}_{\alpha}(\mathrm{Au})$ and $\mathrm{Pb} \mathrm{L}_{\alpha}$ (galena).

\section{Results and Discussion}

Initially, a series of test experiments were conducted to find working experimental parameters. Time required for the attainment of equilibrium were determined by a time series. Criteria for a successful experiment was that the three 
phases (slag, liquid $\mathrm{Cu}-\mathrm{Fe}-\mathrm{Ni}$ alloy and solid Fe-rich alloy) were present in areas large enough for microanalysis in situ. For possible laser ablation studies, the optimal results would require $100 \mu \mathrm{m} \times 100 \mu \mathrm{m}$ sized areas in minimum. Finally, we analyzed with EPMA the chemical compositions of the liquid $\mathrm{Cu}-\mathrm{Fe}-\mathrm{Ni}$ alloy, molten slag and metallic, solid Fe-rich phases in eight quenched samples - two from each Cu-Fe-Ni alloy of different Fe:Ni ratios. Eight individual measurements from each phase but different locations were taken from well-quenched areas in each sample. The total values in all the original measurements were between $97 \mathrm{wt}-\%-101 \mathrm{wt}-\%$, which are considered good. In each sample, the concentrations of $\mathrm{Ag}, \mathrm{Sb}$ and $\mathrm{Pb}$ of about $1 \mathrm{wt}-\%$ could be analysed from the molten $\mathrm{Cu}-$ Fe-Ni alloy and much smaller concentrations in the slag phase. Composition of the gas phase was not analysed in this study as the focus was on the distribution of trace elements between the condensed phases.

\section{Trace element distributions}

From the measured concentrations of $\mathrm{Ag}, \mathrm{Au}, \mathrm{Sb}$ and $\mathrm{Pb}$ by EPMA the distribution coefficients between the liquid $\mathrm{Cu}-\mathrm{Fe}-\mathrm{Ni}$ alloy and molten iron silicate slag were calculated as $\mathrm{L}^{\mathrm{Me} / \mathrm{S}}(\mathrm{M})=(\mathrm{wt}-\% \mathrm{M}) /[\mathrm{wt}-\% \mathrm{M}]$. Figure 3 shows that all of the studied elements report strongly to the molten $\mathrm{Cu}-\mathrm{Fe}-\mathrm{Ni}$ alloy phase in nickel slag cleaning conditions, near the saturation of the alloy with pure iron. This is in agreement with the initial hypothesis.

In addition, $\mathrm{Ag}$ shows a slight increasing trend with increasing iron content in the alloy, while in the case of $\mathrm{Pb}$ a similar increase is more pronounced. The case for $\mathrm{Sb}$ shows a slight decrease as the iron content in the alloy increases. Surprisingly, the results for Au show large scatter. One explanation for this may be that the detected concentrations of $\mathrm{Au}$, and the other traces in the slag, were clearly below the detection limits of EPMA (Ag: 400, $\mathrm{Au}: 610, \mathrm{~Pb}: 320$, and $\mathrm{Sb}: 190 \mathrm{ppm}$ ), causing severe uncertainty in the analysis. Due to the large values of the distribution coefficients, the EPMA measured values for slag for example, indicating very low concentrations in the slag, may be rather imprecise and indicate a lower value of the true distribution coefficients. An improvement will be attained with more sensitive analytical techniques, i.e. LA-ICP-MS [7] to be used for further studies of the present samples in a near future.

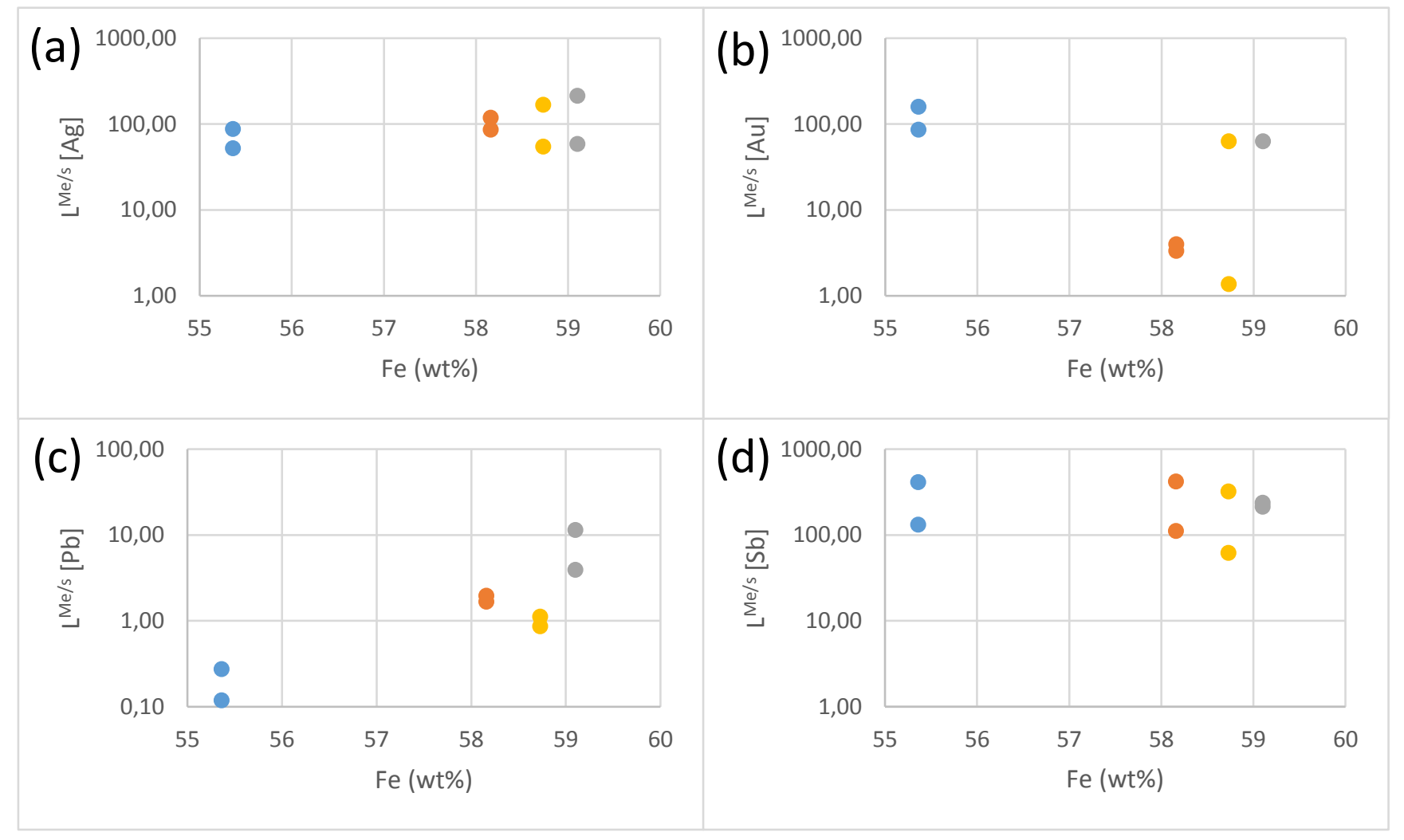

Figure 3(a)-(d). Experimental distribution coefficients of $\mathrm{Ag}, \mathrm{Au}, \mathrm{Pb}$ and $\mathrm{Sb}$ between the liquid $\mathrm{Cu}-\mathrm{Fe}-\mathrm{Ni}$ alloy and iron silicate slag as a function of Fe concentration of the alloy at $1400{ }^{\circ} \mathrm{C}$. 
Table II shows the normalized $\mathrm{SiO}_{2}$ and $\mathrm{K}_{2} \mathrm{O}$ concentrations of the slag phase analysed from the samples. The values obtained for each slag in Table II are averages from two different samples and eight different analysis locations in each sample. Table II shows that the $\mathrm{SiO}_{2}$ and $\mathrm{K}_{2} \mathrm{O}$ concentration are close to the estimated target values of 32 wt- $\%$ of $\mathrm{SiO}_{2}$ and 2 wt- $\%$ of $\mathrm{K}_{2} \mathrm{O}$, respectively. Deviations between the target and measured $\mathrm{SiO}_{2}$ concentrations may be caused by uncertainties from the preparation of the original sample mixtures. For example, $\mathrm{SiO}_{2}$ was added as pure $\mathrm{SiO}_{2}$ and as a mixture containing approximately $90 \% \mathrm{SiO}_{2}$ and $10 \% \mathrm{~K}_{2} \mathrm{O}$. Thus, control of the exact amounts of $\mathrm{SiO}_{2}$ and $\mathrm{K}_{2} \mathrm{O}$ in the mixture was unobtainable. In addition, the concentration of $\mathrm{K}_{2} \mathrm{O}$ in the slag affects the solubility of $\mathrm{SiO}_{2}$. Thermodynamically, as the system has two degrees of freedom at the experimental conditions, it should be possible to fix the $\mathrm{SiO}_{2}$ concentration of the slag. However, as the activity of $\mathrm{Fe}$ and $\mathrm{FeO}$ is fixed, it may affect the equilibrium concentration in each case. In this work, the accuracy of the EPMA measurements was determined by measuring a standard sample (section 2.3). Acceptable deviation from the nominal value of the standard sample was $1 \mathrm{wt} \%$. Due to the high totals of the original measurements and the standards used, the accuracy of the EPMA measurements in this work is considered good.

Table II. Normalised $\mathrm{SiO}_{2}, \mathrm{FeO}$ and $\mathrm{K}_{2} \mathrm{O}$ concentrations in the slag in equilibrium with the different $\mathrm{Cu}-\mathrm{Fe}-\mathrm{Ni}$ alloy compositions, calculated from the EPMA analysed $\mathrm{Si}$ and $\mathrm{K}$ concentrations.

\begin{tabular}{|c|c|c|c|c|c|c|}
\hline Alloy & $\mathrm{SiO}_{2}(\mathrm{wt}-\%)$ & $\mathrm{StDev}$ & $\mathrm{FeO}$ & $\mathrm{StDev}$ & $\mathrm{K}_{2} \mathrm{O}$ (wt-\%) & StDev \\
\hline $\mathrm{I}(40 / 60)$ & 30.86 & 3.62 & 67,80 & 3,50 & 1.34 & 0.47 \\
\hline $\mathrm{II}(50 / 50)$ & 36.64 & 4.10 & 61,85 & 5,17 & 1.51 & 0.61 \\
\hline $\mathrm{III}(60 / 40)$ & 34.18 & 1.00 & 64,09 & 1,21 & 1.74 & 0.22 \\
\hline IV $(70 / 30)$ & 33.74 & 1.05 & 64,89 & 1,12 & 1.37 & 0.40 \\
\hline
\end{tabular}

During experimentation, it was discovered that the thin iron foil crucible reacted with the molten alloy sample forming holes and causing the slag to react locally with the quartz ampoule. Thus, to ensure that the sample was in solid Fe alloy saturation, criteria for a successful experiment was that solid Fe-rich alloy coexisted with the molten slag and $\mathrm{Cu}-\mathrm{Fe}-\mathrm{Ni}$ phases after experiment. The Fe-rich alloy contained $0.1-9.2 \mathrm{wt} \% \mathrm{Cu}$ and 0.1 to $21.6 \mathrm{wt} \% \mathrm{Ni}$.

In addition to this phenomenon, quenching of the molten $\mathrm{Cu}-\mathrm{Fe}-\mathrm{Ni}$ alloy into a single homogeneous phase was found to be very challenging. The solidifying $\mathrm{Cu}-\mathrm{Fe}-\mathrm{Ni}$ alloy often segregated into a $\mathrm{Cu}$-rich phase and $\mathrm{Fe}-\mathrm{Ni}$ rich phase in quenching, resembling the presence of miscibility gap in the copper-iron binary system [11] and its extension to the ternary alloys. It is possible that the presence of trace elements, such as lead and possibly silver, enhances this behavior [11]. Moreover, bright spots in the $\mathrm{Cu}$-rich areas containing larger concentrations of the trace elements than the iron-rich matrix. 


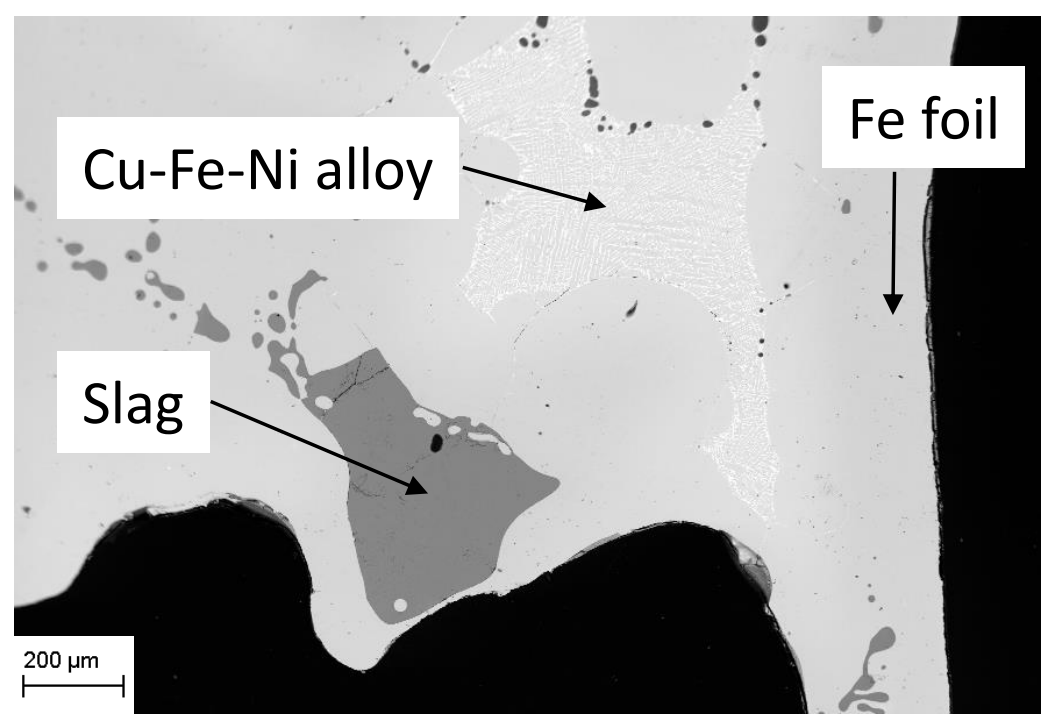

Figure 4. Quenched microstructure of a sample containing the molten $\mathrm{Cu}-\mathrm{Fe}-\mathrm{Ni}$ alloy III (Table III).

\section{Liquid Cu-Fe-Ni alloy phase}

Visual differentiation of the $\mathrm{Cu}-\mathrm{Fe}-\mathrm{Ni}$ molten alloy from the solid metallic iron alloy after quenching in BSE image was sometimes difficult because the metals start to form an alloy, generating the tie-line, between the solid and liquid alloys. At the same time, the composition of the liquid alloy moves towards the Fe corner of the ternary system. In addition, high-purity iron foil dissolves nickel and copper.

According to phase equilibria of the $\mathrm{Cu}-\mathrm{Fe}-\mathrm{Ni}$ system, pure $\mathrm{Fe}$ is unstable at $1400{ }^{\circ} \mathrm{C}$ [11]. Instead, it dissolves into a liquid $\mathrm{Cu}-\mathrm{Fe}-\mathrm{Ni}$ alloy and a $(\gamma \mathrm{Fe}, \mathrm{Ni})$ solid phase which constitute the equilibrium phase-assemblage. The $(\gamma \mathrm{Fe}$, $\mathrm{Ni}$ ) phase is an extended solid solution able to dissolve $\mathrm{Cu}$. Initially, the solid $\mathrm{Fe}$ and the $(\gamma \mathrm{Fe}, \mathrm{Ni}$ ) alloy form a diffusion couple and the equilibrium is first obtained in a reaction layer next to their interphase. Due to this phenomenon, a profile from the boundary between the molten $\mathrm{Cu}-\mathrm{Fe}-\mathrm{Ni}$ alloy and slag towards the pure Fe-foil was measured to determine the size of the molten $\mathrm{Cu}-\mathrm{Fe}-\mathrm{Ni}$ phase and the extent of diffusion and formation of the $(\gamma \mathrm{Fe}$, $\mathrm{Ni})$ solid solution phase.

Average oxygen amounts of $0.27,0.55,0.57$ and $0.52 \mathrm{wt} \%$ were analysed by EPMA in the Cu-Fe-Ni alloys I-IV, respectively, as traces of the sample preparation and forming a typical surface contamination by atmospheric interactions.

Table III. Targets and the measured Fe/Ni ratios (w/w) and compositions of the synthesized $\mathrm{Cu}-\mathrm{Fe}-\mathrm{Ni}$ alloys.

\begin{tabular}{|c|c|c|c|c|c|c|c|c|c|c|c|}
\hline $\begin{array}{c}\text { Alloy \# } \\
\text { target } \mathrm{Fe} / \mathrm{Ni}\end{array}$ & $\begin{array}{c}\mathrm{Fe} / \mathrm{Ni} \\
\text { original }\end{array}$ & $\begin{array}{c}\mathrm{Fe} / \mathrm{Ni} \\
\text { equilibrated }\end{array}$ & $\begin{array}{c}\mathrm{Fe} \\
(\mathrm{wt}-\%)\end{array}$ & & & $\begin{array}{c}\mathrm{Ni} \\
\text { (wt-\%) }\end{array}$ & & & $\begin{array}{c}\mathrm{Cu} \\
(\mathrm{wt}-\%)\end{array}$ & & \\
\hline & & & Initial & Equilibrated & Stdev & Initial & Equilibrated & Stdev & Initial & Equilibrated & Stdev \\
\hline I $(40 / 60)$ & $43 / 57$ & $65 / 35$ & 30.9 & 55.4 & 0.39 & 40.6 & 29.5 & 0.30 & 28.6 & 15.1 & 0.55 \\
\hline II $(50 / 50)$ & $51 / 49$ & $71 / 29$ & 37.5 & 58.2 & 0.39 & 35.3 & 23.4 & 0.22 & 27.2 & 18.4 & 0.48 \\
\hline III $(60 / 40)$ & $60 / 40$ & $74 / 26$ & 45.9 & 59.1 & 1.26 & 30.8 & 20.8 & 1.44 & 23.2 & 20.1 & 2.13 \\
\hline IV $(70 / 30)$ & $70 / 30$ & $77 / 23$ & 46.7 & 58.7 & 2.01 & 20.0 & 17.8 & 2.66 & 33.3 & 23.4 & 1.09 \\
\hline
\end{tabular}




\section{Conclusions}

A novel method to study the behavior of easily volatile elements in nickel slag cleaning electric furnace conditions close to iron saturation was developed. The results indicate that the semi-closed ampoule may be used to study these volatile elements, as significant fractions of the initial, weighed amounts of the volatile $\mathrm{Ag}, \mathrm{Pb}$ and $\mathrm{Sb}$ could be found in the equilibrated slag-alloy samples. This result indicates that the semi-closed ampoule method adopted is very useful in studying the behavior of these easily volatilizing trace elements in various slag-metal and slag-matte systems. Because the method is based on the formation of a kinetic barrier to slow down the movement of the saturated gas phase from the ampoule and thus decreasing the rate of volatilization, the concentrations of these elements in the gas phase are irrelevant in the calculation of the distribution coefficients between the condensed phases. In equilibrium, these coefficients are independent of the amounts of the materials present in the phases.

Distribution of $\mathrm{Ag}, \mathrm{Au}, \mathrm{Pb}$ and $\mathrm{Sb}$ between liquid $\mathrm{Cu}-\mathrm{Fe}-\mathrm{Ni}$ alloy and molten iron silicate slag were studied at 1400 ${ }^{\circ} \mathrm{C}$ in metallic Fe saturation. The experimental series were carried out in inert atmosphere and nickel concentrations in the molten alloy ranged from 20 to $40 \mathrm{wt}-\%$. It was found that all the studied elements distribute preferentially to the liquid metallic $\mathrm{Cu}-\mathrm{Fe}-\mathrm{Ni}$ alloy phase under the studied conditions.

Quenching the liquid $\mathrm{Cu}-\mathrm{Fe}-\mathrm{Ni}$ alloy caused uncertainties in the study of this particular system using a quartz ampoule where the cooling rates were much lower than with low-mass, open samples. The obtained distribution coefficients for volatile elements, e.g. antimony, between metal and slag are lower than reported earlier [5] by about one order of magnitude. This may be a result of systematic depleting the slag phase from the trace element due to volatilization, which is very difficult to discover in the crucible equilibration-sampling measurements.

\section{Acknowledgements}

The authors would like to thank Boliden Harjavalta and CMEco project of Tekes for the financial support of this project. Mr. Lassi Pakkanen and the Finnish Geological Survey are acknowledged for the EPMA measurements.

\section{References}

[1] F.K. Crundwell, M.S. Moats, V. Ramachandran, T.G. Robinson, W.G. Davenport (Eds.) (2011): Extractive Metallurgy of Nickel, Cobalt and Platinum Group Metals. Appendix E - recovering nickel-, copper-, cobalt- and platinum-group elements from slag, Elsevier, Oxford, p. 567-574.

[2] Yazawa A. (1980): Distribution of various elements between copper, matte and slag, Erzmetall, 33: 377-382.

[3] T. Tirronen, D. Sukhomlinov, H. O'Brien, P. Taskinen, M. Lundström (2017): Distributions of lithium-ion and nickel-metal hydride battery elements in copper converting, J Clean. Prod. 168: 399-409.

[4] Chen J., Allen C., Hayes P.C., Jak E. (2016): Experimental Study of Slag/Matte/Metal/Tridymite Four Phase Equilibria and Minor Element Distribution in "Cu-Fe-Si-O" System by Quantitative Microanalysis Techniques. Proc. $10^{\text {th }}$ Int. Conf. Molten Slags (MOLTEN16) (Ed. Reddy R., Chaubal P., Pal U.). TMS, Warrendale (PA), p. 961-970.

[5] Pagador R.U., Hino M., Itagaki K. (1999): Distribution of Minor Elements between MgO Saturated FeOx-MgO$\mathrm{SiO}_{2}$ or FeOx-CaO-MgO-SiO${ }_{2}$ Slag and Nickel Alloy. Mater. Trans. JIM, 40 (3): 225-232.

[6] Taskinen P., Seppälä K., Laulumaa J., Poijärvi J. (2001): Oxygen Pressure in Outokumpu Flash Smelting Furnace. Part II. The DON Process. Trans. IMM, Sect. C, 110 (2): 101-108.

[7] Avarmaa K., O'Brien H., Johto H., Taskinen P. (2015): Equilibrium Distribution of Precious Metals between Slag and Copper Matte at 1250-1350 ${ }^{\circ} \mathrm{C}$. J. Sustain. Metall., 1 (3): 216-228.

[8] R.H. Davies, A.T. Dinsdale, J.A. Gisby, J. Robinson, S.M. Martin (2002): MTDATA - thermodynamics and phase equilibrium software from the national physical laboratory, Calphad. 26: 229-271.

[9] Mäkinen T., Taskinen P. (2008): State of the Art in Nickel Smelting: Direct Outokumpu Nickel Technology, Trans. IMM. Sect. C, 117 (2): 86-94. 
[10] Hellstén N., Hamuyuni J., Taskinen P. (2015): High-Temperature Solubilities in the Cu-O-MgO System at Metallic Copper Saturation, in: Proc. European Metall. Conf. EMC 2015, Vol. 1. GDBM, Clausthal-Zellerfeld, p. 47-60.

[11] Dreval L.A., Turchanin M.A., Agraval P.G. (2014): Thermodynamic assessment of the Cu-Fe-Ni system. J. All. Comp., 587 (1): 533-543. 